\title{
CORRESPONDENCE
}

\section{Diagnosis and treatment of pulmonary tuberculosis}

\section{To the Editor:}

I read with interest the paper by AктоGu' ${ }^{\vee}$ et al. [1] dealing with the epidemiology of pulmonary tuberculosis (PT), in which there are several aspects that deserve further attention.

It shocked me to see one of the criteria for the diagnosis of TB proposed by the authors (a person has tuberculosis (TB) if he/she fulfils at least one of them). I agree with the first criterion (bacteriological proof of infection by Mycobacterium tuberculosis) and I accept the second and third criteria (biopsy showing caseating granulomas and clinical and radiological presentation consistent with TB with marked improvement after specific therapy), but I cannot accept the fourth criterion ("a history of contact with current disease and positive reaction to the 5 tuberculin unit (TU) purified protein derivative (PPD) $(\check{S} 10 \mathrm{~mm}$ induration)"). It seems as if the authors have confused infection with disease and it would, therefore, be interesting to know how many patients (and "active expatients") fulfil each diagnostic criterion.
It was somewhat surprising to see that as many as $17.45 \%$ of patients do not have a bacteriological diagnosis (of these, $18.56 \%$ had not even undergone any bacteriological study); in the USA $9.4 \%$ of all PT patients do not have bacteriological proof of disease and this figure has been considered to be extremely high [2]. Once again, it would be interesting to know how many patients fulfil each diagnostic criterion among those without positive bacteriological studies (i.e. with negative or with no bacteriological studies).

\section{A. Díez Herranz}

C/Puente Colgante, 28, $1^{\circ} \mathrm{D}, 47007$ Valladolid, Spain. Fax: 34983397430.

\section{References}

1. Aktoğu S, Yorgancioğlu A, Çirak K, Köse T, Dereli SM Clinical spectrum of pulmonary and pleural tuberculosis, a report of 5,480 cases. Eur Respir J 1996; 9: 2031-2035.

2. Rossman MD, Mayock RL. Tuberculosis pulmonar. In: Rossman MD, MacGregor RP, eds. Tuberculosis. Mexico, McGraw Hill-Interamericana, 1996; pp. 159-170.

\section{REPLY}

\section{From the authors:}

We would like to thank A.D. Herranz for his comments concerning our article. Firstly, it is quite clear that our methodology regarding diagnostic criteria has been misunderstood. None of our patients were diagnosed as having tuberculosis (TB) on the basis of only the fourth criterion. Based on the diagnostic criteria, the classification of all patients was as follows: 1) there were 4,205 (77\%) patients with first and third criteria. This group included some patients who also had the second and/or fourth criteria; 2) $386(7 \%)$ patients fulfilled the second and third criteria with or without the fourth criterion; 3 ) $646(12 \%)$ patients fulfilled the third and fourth criteria; and 4) in $243(4 \%)$ patients, diagnosis was established on the basis of the third criterion only. Of 1,212 active expatients, 1,009 cases fulfilled the first and third criteria. This group included some patients with additional second and/ or fourth criteria, while 203 patients fulfilled the third and fourth criteria with or without the second criteria.

Secondly, the rate of the diagnosis without bacteriological confirmation is not surprising, for various reasons. Some patients had already started antimycobacterial medication or received an interrupted treatment before their admission to the hospital. The Ziehl-Neelsen (Z-N) staining and conventional solid Löwenstein-Jensen (L-J) media are available in our hospital. Auramine-rhodamine staining appears to be more sensitive than classic Z-N stains [1]. Middlebrook plate media, Septic-Check acid-fast bacillus system and BACTEC methods are also better than conventional L-J media [2-4]. A combination of solid plus liquid media is the current gold standard for accurate detection of mycobacteria in culture [5]. As the diagnostic value of bacteriological studies varies partly according to the method used, this aspect of our study is not comparable to that of some other series.

\section{S. Aktoğu*, A. Yorgancioğlu*, K. Çurak*, T. Köse+,} S.M. Dereli*

*Izmir Training Hospital for Thoracic Medicine and Surgery, 35110, Izmir, Turkey. +Faculty of Computer Engineering, Ege University, Izmir, Turkey. Fax: 902324587262.

\section{References}

1. Marshall BG, Shaw RJ. Diagnostic techniques: old and new. Eur Respir Mon 1997; 4: 30-50.

2. Wilson ML, Stone BL, Hildred MV, Reves RR. Comparison of recovery rates for mycobacteria from BACTEC $12 \mathrm{~B}$ vials, middlebrook $7 \mathrm{H} 11$-selective $7 \mathrm{H} 11$ biplates, and Löwenstein-Jensen slants in a public health mycobacteriology laboratory. J Clin Microbiol 1995; 33: 2516-2518.

3. Sewel DL, Rashad AL, Rourke WJ, et al. Comparison of the Septi-Check AFB and BACTEC systems and conventional culture for recovery of mycobacteria. J Clin Microbiol 1993; 31: 2689-2691.

4. Zanetti S, Ardito F, Sechi L, et al. Evaluation of a nonradiometric system (BACTEC $9000 \mathrm{MB}$ ) for detection of mycobacteria in human clinical samples. J Clin Microbiol 1997; 35: 2072-2075.

5. Nolte FS, Metchock B. Mycobacterium. In: Murray PR, Baron EJ, Pfaller MA, Tenover FC, Yolken RH, eds. Manual of Clinical Microbiology, 6th Edn. Washington DC, ASM Press, 1995; pp. 400-437. 